\title{
FAKTOR-FAKTOR YANG MEMPENGARUHI KEJADIAN LESI PRA KANKER
}

\author{
Ferdianti Enggoa, Rachmawati, Ratna Dewi \\ Politeknik Kesehatan Kementerian Kesehatan Bengkulu, Jurusan Kebidanan \\ Jalan Indragiri Nomor 03 Padang Harapan Kota Bengkulu \\ jmkbengkulu@gmail.com
}

\begin{abstract}
The prevalence of cervical cancer in Indonesia is estimated in every day that 41 new cases of cervical cancer and about 20 people every day die. Bengkulu province ranked fourth with a prevalence of cancer of $1.9 \%$ with the total number of cervical cancer patients in 2015 as many as 705 cases. Early detection of pre-cancerous lesions through IVA test. Factors affecting pre-cancerous lesions consist of marital age, age, parity and hormonal contraceptive use. The purpose of this research is to know the factors that influence the incidence of pre-cancer lesions in the Region of Puskesmas Care Kembang Seri Talang Empat Sub-district, Central Bengkulu Regency Year 2017. This research is analytical descriptive research with case control design. Samples A case group of women with positive IVA test results of 36 people with total sampling technique and women's control group with negative IVA test results with a 1: 1 comparison was taken with a simple random technique. Data were analyzed using Chi-Square test and Binary Logistic Regression. The results showed that nearly half of the respondents had positive pre-cancerous lesions, mostly married $\leq 20$ years, most of the use of hormonal contraceptives $\geq 5$ know, most respondents were mother's age> 35 years and mostly. There is a relationship of married age, the use of hormonal contraceptives and parity to the incidence of pre-cervical cancer lesions and no relationship of maternal age with the incidence of cervical pre-cancer lesions The most influential factor on the incidence of pre-cancerous lesions is married age. It is hoped that Puskesmas should be able to coordinate and cooperate with cross-sectional about the age of menikha that must be done at age $>20$ years and do ekrjasama with school parties to prevent teenage pregnancy by doing cooperation with organization of PIK-R.
\end{abstract}

Keywords: Hormonal Contraceptives, Pre-Cancer Lesions, Parity, Married Age, Mother Age

\begin{abstract}
Abstrak:Prevalensi kanker serviks di Indonesia di perkirakan dalam setiap harinya terjadi 41 kasus baru kanker serviks dan sekitar 20 orang setiap harinya meninggal dunia. Propinsi Bengkulu menduduki peringkat ke empat prevalensi kanker yaitu 1,9\% dengan jumlah total penderita kanker serviks pada tahun 2015 sebanyak 705 kasus. Deteksi dini terjadinya lesi pra kanker melalui pemeriksaan IVA test. Faktor-faktor yang mempengaruhi lesi pra kanker terdiri dari kebiasaan usia menikah, usia, paritas dan penggunaan kontrasepsi hormonal. Tujuan penelitian untuk mengetahui faktor-faktor yang mempengaruhi kejadian lesi pra kanker di Wilayah Puskesmas Perawatan Kembang Seri Kecamatan Talang Empat Kabupaten Bengkulu Tengah Tahun 2017.Penelitian ini adalah penelitian deskriptif analitik dengan rancangan case control. Sampel Kelompok kasus wanita dengan hasil IVA test positif sebanyak 36 orang dengan tekhnik total sampling dan kelompok kontrol wanita dengan hasil IVA test negatif dengan pembanding 1:1 diambil dengan tekhnik simple random. Data dianalisis menggunakan uji Chi-Square dan Regresi Binary Logistic. Hasil penelitian didapatkan bahwa Hampir setengah responden lesi pra kanker positif, Sebagian besar menikah $\leq 20$ tahun, sebagian besar penggunaan kontrasepsi hormonal $\geq 5$ tahu, sebagian besar responden usia ibu >35 tahun dan sebagian besar. Ada hubungan usia menikah, penggunaan kontrasepsi hormonal dan paritas terhadap kejadian lesi pra kanker serviks dan tidak ada hubungan usia ibu dengan kejadian lesi pra kanker serviks Faktor yang
\end{abstract}


paling berpengaruh terhadap kejadian lesi pra kanker adalah usia menikah. Diharapkan Puskesmas hendaknya bisa melakukan koordinasi dan kerja sama dengan lintas sektor mengenai usia menikha yang harus dilakukan pada umur $>20$ tahun dan melakukan ekrjasama dengan pihak-pihak sekolah untuk mencegah terjadinya kehamilan remaja dengan cara melakukan kerja sama dengan organisasi PIK-R.

Kata Kunci: Kontrasepsi Hormonal, Lesi Pra Kanker, Paritas, Usia Menikah, Usia Ibu

Lesi pra kanker leher rahim yang sangat dini dikenal dengan Neoplasi Intraepitelial Serviks atau NIS, yang ditandai dengan adanya perubahan displastik epitel serviks. Keadaan ini merupakan awal dari perubahan menuju karsinoma leher rahim (Andrijono, 2010). Kanker leher rahim (kanker serviks) merupakan tumor ganas yang tumbuh di dalam leher rahim yang menempel pada puncak vagina (Prayitno, 2014). Kanker serviks merupakan penyebab keempat kematian kanker serviks didunia. Data yang didapatkan dari Intitut Catala Oncologia (ICO) Human Papiloma Virus Information Centre tahun 2017 didapatkan data bahwa didapatkan 527.625 kasus kanker serviks di dunia, sebanyak 265.672 orang (ICO HPV Information Centre, 2017)

Prevalensi kanker serviks di Indonesia di perkirakan dalam setiap harinya terjadi 41 kasus baru kanker serviks dan sekitar 20 orang setiap harinya meninggal dunia. Prevalensi kanker serviks tertinggi berada di Yogyakarta $(4,1 \%)$, kedua Jawa Tengah $(2,1 \%)$ dan ke tiga Bali (2\%). Prevalensi kanker serviks pada bayi $0,3 \%$ dan meningkat pada umur $>15$ tahun dan tertinggi pada umur $>75$ tahun $15 \%$ (Riset Kesehatan Dasar, 2013). Propinsi Bengkulu menduduki peringkat ke empat prevalensi kanker yaitu 1,9\% dengan jumlah total penderita kanker serviks pada tahun 2015 sebanyak 705 kasus (Kemenkes RI, 2015). Deteksi dini kanker serviks melalui metode IVA di provinsi Bengkulu tertinggi di Kabupaten Bengkulu Tengah sebanyak 71 kasus (17,36\%), kedua Kabupaten Rejang Lebong sebanyak 22 kasus $(5,06 \%)$ dan yang ke tiga Kota Bengkulu sebanyak 15 kasus $(4,60 \%)$ (Dinas Kesehatan Provinsi Bengkulu, 2015).

Inpeksi Visual Asam Asetat (IVA) merupakan salah satu deteksi dini kanker serviks dengan menggunakan asam asetat 3-5 $\%$ secara inspekulo dan dilihat dengan pengamatan mata langsung (mata telanjang). Pemeriksaan ini tidak menimbulkan rasa sakit, mudah, murah dan informasi hasilnya langsung (Nugroho, 2010). Hasil dari pemeriksaan IVA nantinya yang akan diketahui apakah terjadi lesi pra kanker atau tidak. Deteksi dini terjadinya lesi pra kanker melalui pemeriksaan IVA test termasuk juga dalam visi misi Kebidanan Politeknik Kesehatan Kementerian Kesehatan Bengkulu yaitu melakukan deteksi dini masalah-masalah kebidanan di komunitas (Jurusan Kebidanan Poltekkes Kemenkes Bengkulu, 2017). Faktor-faktor yang mempengaruhi lesi pra kanker terdiri dari kebiasaan usia menikah, usia, paritas dan penggunaan kontrasepsi hormonal (Nindrea, 2017 dan Wahyuningsih, dkk 2014).

Usia pertama melakukan hubungan seks pada umur di bawah 17 tahun merangsang tumbuhnya sel kanker pada alat kandungan perempuan. Penelitian Putra (2012) menyebutkan bahwa kejadian lesi pra kanker serviks dan usia perkawinan < 21 tahun memiliki rasio prevalensi sebesar 2,11 kali lebih besar daripada usia perkawinan $>20$ tahun untuk mengalami lesi pra kanker serviks. Selanjutnya, usia $>35$ tahun lebih beresiko untuk terjadinya lesi berkaitan dengan lamanya pemaparan terhadap karsinogen serta makin melemahnya sistem kekebalan tubuh karena bertambahnya umur. Hasil penelitian Wahyuningsih, dkk (2014), Responden yang mengalami lesi pra kanker serviks pada perempuan yang berumur $\geq 35$ tahun berisiko 5,86 kali untuk mengalami kejadian lesi pra kanker serviks dibanding mereka yang berumur < 35 tahun. Kontrasepsi hormonal memicu terjadinya perubahan pada epitel leher rahim diduga akibat estrogen menginduksi onkogenesis secara langsung pada epitel leher rahim. Penelitian Parwati, dkk (2015) Wanita PUS yang menggunakan kontrasepsi hormonal $>5$ tahun memiliki risiko 10,7 kali lebih tinggi mengalami lesi pra kanker leher rahim dibandingkan dengan yang tidak menggunakan kontrasepsi hormonal, dan penggunaan <5 tahun meningkatkan risiko sebesar 3,0 kali lebih tinggi dibandingkan dengan wanita PUS 
yang tidak menggunakan kontrasepsi hormonal.

Paritas berkaitan dengan keluarnya janin yang akan mengakibatkan trauma pada serviks, sehingga apabila serviks semakin sering mengalami kelahiran maka serviks akan lebih sering mengalami trauma, yang mengakibatkan bisa masuknya virus HPV yang bisa berujung menyebabkan kanker (Maharani, 2009). Hasil penelitian Putra (2012) menyebutkan bahwa mereka yang pernah melahirkan lebih dari 3 kali dapat meningkatkan angka kejadian kanker sebanyak 3 kali lipat.

Data dinas kesehatan Kabupaten Bengkulu Tengah Puskesmas Kembang Seri paling banyak kasus IVA positif dengan jumlah 36 kasus $(24,06 \%)$ dari 137 orang wanita yang melakukan pemeriksaan IVA, kedua Puskesmas Karang Tinggi dengan jumlah kasus 14 orang $(15,73 \%)$, Ketiga Puskesmas Taba Lagan dengan jumlah kasus 5 orang (10,20\%) (Dinkes Bengkulu Tengah, 2016). Survey awal yang dilakukan di Puskesmas Kabupaten Bengkulu Tengah tanggal 20 November tahun 2017 didapatkan dari 5 orang IVA positif mempunyai paritas $>3$ sebanyak 3 orang, usia menikah $<20$ tahun 4 orang, penggunaan kontrasepsi hormonal $>5$ tahun sebanyak 3 orang dan usia ibu $>35$ tahun sebanyak 4 orang. Data ini menunjukkan bahwa masih tingginya kejadian lesi pra kanker di Puskesmas Karang Tinggi Kabupaten Bengkulu Tengah. Sehingga perlu diadakannya penelitian mengenai faktor-faktor yang mempengaruhi kejadian lesi pra kanker di Wilayah Puskesmas Perawatan Kembang Seri Kecamatan Talang Empat Kabupaten Bengkulu Tengah Tahun 2017

\section{BAHAN DAN CARA KERJA}

Penelitian ini adalah penelitian deskriptif analitik dengan rancangan case control. Sampel Kelompok kasus wanita dengan hasil IVA test positif sebanyak 36 orang dengan tekhnik total sampling dan kelompok kontrol wanita dengan hasil IVA test negatif dengan pembanding 1:1 diambil dengan tekhnik simple random. Data dianalisis menggunakan uji Chi-Square dan Regresi Binary Logistic.

\section{HASIL}

Tabel 1 Distribusi frekuensi Lesi Pra Kanker, usia menikah, penggunaan kontraspesi hormonal, usia ibu dan paritas di Wilayah Puskesmas Kembang Seri Kabupaten Bengkulu Tengah Tahun 2016

\begin{tabular}{lcc}
\hline Variabel & Jumlah & \% \\
\hline Lesi Pra Kanker & & \\
Lesi pra kanker positif & 36 & 50.0 \\
Lesi pra kanker negatif & 36 & 50.0 \\
\hline Usia Menikah & & \\
Menikah $\leq 20$ tahun & 42 & 58.3 \\
Menikah >20 tahun & 30 & 41.7 \\
\hline Usia Ibu & & \\
$>35$ tahun & 59 & 81.9 \\
20-35 tahun & 13 & 18.1 \\
\hline Paritas & & \\
Anak yang dilahirkan $\geq 3$ & 20 & 27.8 \\
Anak yang dilahirkan $<3$ & 52 & 72.2 \\
\hline
\end{tabular}

Hasil penelitian hampir setengah responden $(50 \%)$ lesi pra kanker positif, sebagian besar (58.3\%) menikah $\leq 20$ tahun 20 tahun, hampir seluruh $(81.9 \%)$ usia ibu $>35$ tahun dan sebagian besar (72.2\%) anak yang dilahirkan $<3$

Tabel 2 Hubungan usia menikah, penggunaan kontraspesi hormonal, usia ibu dan paritas dengan kejadian lesi pra kanker di Wilayah Puskesmas Kembang Seri Kabupaten Bengkulu Tengah Tahun 2016

\begin{tabular}{|c|c|c|c|c|c|c|}
\hline \multirow{3}{*}{ Variabel } & \multicolumn{4}{|c|}{$\begin{array}{c}\text { Kejadian Lesi Pra } \\
\text { Kanker }\end{array}$} & \multirow{3}{*}{$\begin{array}{l}p- \\
\text { valu } \\
e\end{array}$} & \multirow[t]{3}{*}{ OR } \\
\hline & \multicolumn{2}{|c|}{ Positif } & \multicolumn{2}{|c|}{ Negatif } & & \\
\hline & $\mathbf{F}$ & $\%$ & $\mathbf{F}$ & $\%$ & & \\
\hline $\begin{array}{l}\text { Usia } \\
\text { Menikah }\end{array}$ & & & & & 0.00 & $\begin{array}{c}10 \\
(3.271-\end{array}$ \\
\hline $\begin{array}{l}\text { Menikah } \\
\leq 20 \text { tahun }\end{array}$ & 30 & $\begin{array}{l}83 . \\
3\end{array}$ & 4 & $\begin{array}{l}11 . \\
1\end{array}$ & 0 & $30.567)$ \\
\hline $\begin{array}{l}\text { Menikah } \\
>20 \text { tahun }\end{array}$ & 6 & $\begin{array}{l}16 . \\
7\end{array}$ & $\begin{array}{l}3 \\
2\end{array}$ & $\begin{array}{l}88 . \\
9\end{array}$ & & \\
\hline $\begin{array}{l}\text { Usia Ibu } \\
>35 \text { tahun }\end{array}$ & 33 & $\begin{array}{l}91 . \\
7\end{array}$ & $\begin{array}{l}2 \\
6\end{array}$ & $\begin{array}{l}72 . \\
2\end{array}$ & 0.03 & $\begin{array}{c}4.231 \\
(1.055- \\
16.966)\end{array}$ \\
\hline $\begin{array}{l}20-35 \\
\text { tahun }\end{array}$ & 3 & 8.3 & $\begin{array}{l}1 \\
0\end{array}$ & $\begin{array}{l}27 . \\
8\end{array}$ & 2 & \\
\hline $\begin{array}{l}\text { Paritas } \\
\text { Anak yang } \\
\text { dilahirkan } \\
\geq 3\end{array}$ & 6 & $\begin{array}{l}16 . \\
7\end{array}$ & $\begin{array}{l}1 \\
5\end{array}$ & $\begin{array}{l}41 . \\
7\end{array}$ & $\begin{array}{c}0.03 \\
5\end{array}$ & $\begin{array}{c}0.314 \\
(0.104 \\
-0.947)\end{array}$ \\
\hline $\begin{array}{l}\text { Anak yang } \\
\text { dilahirkan } \\
<3\end{array}$ & 30 & $\begin{array}{l}83 . \\
3\end{array}$ & $\begin{array}{l}2 \\
1\end{array}$ & $\begin{array}{l}58 . \\
3\end{array}$ & & \\
\hline
\end{tabular}

Hasil penelitian didapatkan dari 36 responden yang memiliki hasil lesi prakanker positif hampir seluruh $(83.3 \%)$ menikah $\leq 20$ tahun dan dari 36 responden yang memiliki hasil lesi prakanker negatif 
hampir seluruh $(88.9 \%)$ menikah >20 tahun. Hasil uji statistik didapatkan $p=0,000$ ada hubungan usia menikah dengan lesi prakanker. Nilai $\mathrm{OR}=10$ artinya usia menikah $<20$ tahun 10 kali beresiko terjadi lesi prakanker dibandingkan dengan usia menikah >20 tahun. Hasil penelitian didapatkan dari 36 responden yang memiliki hasil lesi prakanker positif hampir seluruh responden $(91.7 \%)$ usia ibu $>35$ tahun dan dari 36 responden yang memiliki hasil lesi prakanker negatif sebagian besar $(72.2 \%)$ usia >35 tahun. Hasil uji statistik didapatkan $p=0,032$ artinya ada hubungan usia ibu dengan lesi prakanker. Nilai $\mathrm{OR}=$ 4.231 artinya usia ibu >35 tahun 4.231 kali beresiko terjadi lesi prakanker dibandingkan dengan usia 20-35 tahun.

Hasil penelitian didapatkan dari 36 responden yang memiliki hasil lesi prakanker positif hampir seluruh responden $(83.3 \%)$ paritas $<3$ dan dari 36 responden yang memiliki hasil lesi prakanker negatif sebagian besar $(58.3 \%)$ paritas <3. Hasil uji statistik didapatkan $p=0,035$ artinya ada paritas dengan lesi prakanker. Nilai $\mathrm{OR}=0.314$ artinya ibu yang melahirkan anak $\geq 3 \quad 0.314$ kali beresiko terjadi lesi prakanker dibandingkan dengan anak $<3$.

Tabel 3 Hasil Analisa Multivariat Menggunakan Regresi Binary Logistic

\begin{tabular}{cllccc}
\hline Model & Variabel & & & \multicolumn{3}{c}{$\begin{array}{c}\text { 95.0\% C.I.for } \\
\text { EXP(B) }\end{array}$} \\
& & & & \multicolumn{3}{c}{ Sig. } & $\operatorname{Exp}(\mathbf{B})$ & Lower & Upper \\
\hline I & Usia menikah & 0.000 & 7.978 & 2.526 & 25.198 \\
& paritas & 0.202 & 0.438 & 0.124 & 1.556 \\
& Usia & 0.239 & 2.584 & 0.533 & 12.529 \\
\hline II & Usia menikah & 0.000 & 9.000 & 2.900 & 27.936 \\
& Paritas & 0.185 & 0.429 & 0.122 & 1.499 \\
\hline \multirow{2}{*}{ III } & Usia menikah & 0.000 & 10.000 & 3.271 & 30.567 \\
\hline & & & & &
\end{tabular}

Hasil tabel 4.3 didapatkan bahwa dari 3 variabel yang dilakukan analisis multivariat pada model I didapatkan bahwa paritas dan usia tidak berpengaruh terhadap kejadian lesi prakanker. Selanjutnya, pada model II didapatkan bahwa paritas tidak berpengaruh terhadap kejadian lesi prakanker. Kemudian, pada model III variabel yang paling berpengaruh adalah usia menikah.

\section{PEMBAHASAN}

\section{Hubungan Usia Menikah dengan Kejadian Lesi Pra Kanker}

Hasil penelitian didapatkan dari 36 responden yang memiliki hasil lesi prakanker positif hampir seluruh $(83.3 \%)$ menikah $\leq 20$ tahun dan dari 36 responden yang memiliki hasil lesi prakanker negatif hampir seluruh $(88.9 \%)$ menikah $>20$ tahun. Hasil uji statistik didapatkan $p=0,000$ ada hubungan usia menikah dengan lesi prakanker. Nilai $\mathrm{OR}=10$ artinya usia menikah $<20$ tahun 10 kali beresiko terjadi lesi prakanker dibandingkan dengan usia menikah $>20$ tahun.

Penelitian Wahyuningsih (2014) didapatkan bahwa umur pertama kali berhubungan seksual merupakan faktor risiko terjadinya kanker serviks, sekitar $20 \%$ kanker serviks dijumpai pada wanita yang aktif berhubungan seksual sebelum berumur 16 tahun. kontak seksual usia muda erat kaitannya dengan terjadinya lesi prakanker serviks. karsinoma serviks cenderung timbul bila saat mulai aktif berhubungan seksual pada saat usia kurang dari 17 tahun. dijelaskan bahwa umur antara 15 - 20 tahun merupakan periode yang rentan. periode rentan ini berhubungan dengan pesatnya proses metaplasia pada usia pubertas, sehingga bila ada yang mengganggu proses metaplasia tersebut misalnya infeksi akan memudahkan beralihnya proses menjadi displasia yang lebih berpotensi untuk terjadinya keganasan.

Hasil penelitian ini sejalan dengan penelitian yang dilakukan Nindrea (2017) 
dari 21 orang yang melakukan hubungan seksual dibawah 20 tahun, sebanyak 14 orang $(66,7 \%)$ lesi pra kanker positif dan juga sejalan dengan penelitian Putra (2012) dimana hasil uji chi square didapatkan nilai PR 2,11 (CI 95\% = 1,274-4.935, $\mathrm{p}=$ $0,034)$ artinya terdapat hubungan yang signifikan antara usia perkawinan $<21$ tahun dengan kejadian lesi prakanker serviks dan usia perkawinan $<21$ tahun memiliki rasio prevalensi sebesar 2,11 kali lebih besar daripada usia perkawinan $>20$ tahun untuk mengalami lesi prakanker serviks. Hasil penelitian didapatkan bahwa ibu yang menikah $<20$ tahun terdapat kejadian lesi prakanker negatif. Hal ini dipengaruhi karena ibu menjaga pola makanan yang sehat, melakukan personal hygiene dengan baik, melakukan test IVA secara berkala, melakukan vaksinasi, tidak merokok dan tidak minum minuman yang beralkohol (Savitri dkk, 2015).

Hal ini didukung oleh penelitian Irmayani (2014) bahwa wanita yang merokok mempunyai kemungkinan 6,333 kali untuk mendapatkan lesi prakanker serviks dibandingkan dengan yang tidak merokok. Penelitian Wahyuningsih (2014) menyebutkan bahwa responden yang merokok mempunyai peluang 3,545 kali lebih besar untuk mengalami lesi prakanker serviks dibandingkan dengan responden yang tidak merokok. Zat-zat karsinogen yang dihasilkan dari rokok sering ditemukan pada serviks wanita yang aktif merokok dan menjadi kokarsinogen infeksi HPV, dengan kata lain merokok akan meningkatkan risiko terkena lesi prakanker serviks.

Hasil penelitian didapatkan bahwa ibu dengan lesi pra kanker lebih dari 20 tahun, namun lesi pra kanker positif. Melakukan seks setelah umur 20 tahun merupakan masa reproduksi aman melakukan hubungan seks karena alat reproduksi sudah matang. Namun, pada kelompok ini tetap terjadi lesi prakanker. Hal ini dipengaruhi oleh paritas, paritas $\geq 3$ beresiko 3 kali lipat untuk terjadi lesi prakanker. Kemudian, bisa juga dipengaruhi kebiasaan personal hygiene yang buruk yang menyebabkan kuman bisa cepat masuk, terlalu sering dalam penggunaan sabun kewanitaan yang tidak sesuai dengan PH-kewanitaan (Syatriani, 2011).

\section{Hubungan Paritas dengan Kejadian Lesi Pra Kanker}

Hasil penelitian didapatkan dari 36 responden yang memiliki hasil lesi prakanker positif hampir seluruh responden $(83.3 \%)$ paritas $<3$ dan dari 36 responden yang memiliki hasil lesi prakanker negatif sebagian besar $(58.3 \%)$ paritas <3. Hasil uji statistik didapatkan $p=0,035$ artinya ada paritas dengan lesi prakanker. Nilai $\mathrm{OR}=0.314$ artinya ibu yang melahirkan anak $\geq 3 \quad 0.314$ kali beresiko terjadi lesi prakanker dibandingkan dengan anak $<3$.

Hasil ini tidak sejalan dengan penelitian Puta (2012) bahwa perempuan dengan paritas tinggi terkait dengan terjadinya eversi epitel kolumner serviks selama kehamilan yang menyebabkan dinamika baru epitel metaplastik imatur yang dapat meningkatkan risiko transformasi sel serta trauma pada serviks sehingga terjadi infeksi HPV persisten. Kemudian, pada mereka yang pernah melahirkan lebih dari 3 kali dapat meningkatkan angka kejadian kanker sebanyak 3 kali lipat.

Selain itu, Tapan (2010) juga mengungkapkan bahwa perlukaan pasca persalinan dapat menjadikan awal terjadinya kanker serviks apabila tidak segera ditangani. Bukan hanya perlukaan pasca persalinan yang menyebabkan terjadinya kanker serviks tetapi jarak persalinan yang terlalu dekat juga dapat menyebabkan terjadinya kanker serviks. Perlukaan setelah melahirkan dan jarak persalinan yang terlalu dekat akan menyebabkan virus penyebab kanker servik masuk. Hasil penelitian ini juga tidak sejalan dengan Wahyuningsih (2014) 
menunjukkan bahwa sebagian besar responden yang memiliki paritas $\geq 3$ kali lebih berisiko mengalami lesi prakanker serviks 24,930 kali lebih besar untuk mengalami lesi prakanker serviks dibanding dengan responden yang memiliki paritas <3 kali. Hasil uji statistik menunjukkan ada hubungan yang signifikan antara paritas dengan kejadian lesi prakanker serviks $(\mathrm{p}<0,05)$. Sejalan juga dengan penelitian yang dilakukan oleh Sogukpinar et al (2013) kelompok wanita yang memiliki paritas lebih dari 3 mempunyai risiko menderita kanker serviks 1,9 kali lebih besar dari pada golongan wanita yang bersalin antara 1 kali.

\section{Hubungan Usia Ibu dengan Lesi Pra Kanker}

Hasil penelitian didapatkan dari 36 responden yang memiliki hasil lesi prakanker positif hampir seluruh responden $(91.7 \%)$ usia ibu $>35$ tahun dan dari 36 responden yang memiliki hasil lesi prakanker negatif sebagian besar $(72.2 \%)$ usia >35 tahun. Hasil uji statistik didapatkan $p=0,032$ artinya ada hubungan usia ibu dengan lesi prakanker. Nilai $\mathrm{OR}=$ 4.231 artinya usia ibu >35 tahun 4.231 kali beresiko terjadi lesi prakanker dibandingkan dengan usia 20-35 tahun.

Bahwa sesuai dengan teori Wahyuningsih (2014) menunjukkan bahwa kanker serviks banyak terjadi pada usia lanjut, risikonya meningkat dua kali lipat setelah umur 35 tahun. Meningkatnya risiko ini merupakan gabungan dari meningkat dan bertambah lamanya pemaparan terhadap karsinogen serta makin melemahnya sistem kekebalan tubuh karena bertambahnya umur. Hasil penelitian ini sejalan dengan

\section{DAFTAR RUJUKAN}

Caturini, dkk.2015. Faktor Lesi Prakanker Serviks Di Rumah Sakit Umum Daerah Ryacudu Kota Bumi Lampung Utara.
Wahyuningsih dkk (2014) bahwa ada hubungan yang signifikan antara umur responden dengan kejadian lesi pra kanker serviks dan responden yang mengalami lesi pra kanker serviks pada perempuan yang berumur $\geq 35$ tahun berisiko 5,86 kali untuk mengalami kejadian lesi pra kanker serviks dibanding mereka yang berumur < 35 tahun. Hasil penelitian ini juga sejalan dengan penelitian Irmayani (2014) menunjukkan ada hubungan antara umur dengan kejadian lesi pra kanker serviks pada wanita pekerja seks dan wanita pekerja seks dengan umur $<25$ tahun mempunyai kemungkinan 5,778 kali untuk mendapatkan lesi pra kanker serviks dibandingkan dengan yang berumur $\geq 25$ tahun.

\section{KESIMPULAN}

Hasil penelitian didapatkan bahwa Hampir setengah responden lesi pra kanker positif, Sebagian besar menikah $\leq 20$ tahun, sebagian besar penggunaan kontrasepsi hormonal $\geq 5$ tahu, sebagian besar responden usia ibu $>35$ tahun dan sebagian besar. Ada hubungan usia menikah, penggunaan kontrasepsi hormonal dan paritas terhadap kejadian lesi pra kanker serviks dan tidak ada hubungan usia ibu dengan kejadian lesi pra kanker serviks Faktor yang paling berpengaruh terhadap kejadian lesi pra kanker adalah usia menikah. Diharapkan Puskesmas hendaknya bisa melakukan koordinasi dan kerja sama dengan lintas sektor mengenai usia menikha yang harus dilakukan pada umur >20 tahun dan melakukan ekrjasama dengan pihak-pihak sekolah untuk mencegah terjadinya kehamilan remaja dengan cara melakukan kerja sama dengan organisasi PIK-R.

Jurnal Dunia Kesmas Volume 4. Nomor 3 Halaman 145-150

Chandrawati. 2016. Faktor Risiko yang Berpengaruh Dengan Kejadian Kanker Serviks Di RSUD Dr. H. Abdul Moeloek 
Provinsi Lampung. Jurnal Kesehatan Volume VII Nomor 2 halaman 282-287

Dinas Kesehatan Bengkulu Tengah.2016. Profil Kesehatan Bengkulu Tengah Tahun 2016. Bengkulu Tengah

Dinas Kesehatan Provinsi Bengkulu. 2015. Profil

Dinas Kesehatan Provinsi Bengkulu. Bengkulu

ICO HPV Information Centre.2017.Human Papillomavirus and Related Diseases Report. HPV Information Centre. Barcelona Irmayani.2014. Faktor Resiko Yang Berhubungan Dengan Lesi Prakanker Serviks Pada Wps Tidak Langsung Di Wilayah Kerja Puskesmas Meninting Tahun 2014. Jurnal Kesehatan Prima Volume 8 Nomor 2

Jurusan Kebidanan Poltekkes Kemenkes Bengkulu. 2017. Visi dan Misi Jurusan Kebidanan Poltekkes Kemenkes Bengkulu. Bengkulu

Kemenkes RI. 2015. Buletin Kanker. Kementerian Kesehatan Republik Indonesia Sekretaris Jenderal. Jakarta

Nindrea.2017.Prevalensi Dan Faktor Yang Mempengaruhi Lesi Pra Kanker Serviks Pada Wanita. Journal Endurance Volume 2 Nomor 1 Halaman 53-61
Parwati, dkk.2015. Kontrasepsi Hormonal dan Riwayat Infeksi Menular Seksual sebagai Faktor Risiko Lesi Pra-kanker Leher Rahim. Public Health and Preventive Medicine Archive Volume 3 Nomor 2 Halaman 173178

Putra.2012.Hubungan Paritas dan Usia Perkawinan Sebagai Faktor Risiko Lesi Prakanker Serviks Pada Ibu Pasangan Usia Subur Di Wilayah Kerja Puskesmas Sukasada II.Skripsi. Program Studi Pendidikan Dokter Fakultas Kedokteran Universitas Udayana

Riset Kesehatan Dasar .2013. Laporan Riset Kesehatan Dasar 2013. Badan Penelitian dan Pengembangan Kesehatan Kementerian RI. Jakarta

Savitri.2015. Kupas tuntas kanker payudara leher rahim dan rahim. Yogyakarta. Pustaka Baru Press.

Wahyuningsih, dkk.2014.Faktor Risiko Terjadinya Lesi Prakanker Serviks Melalui Deteksi Dini Dengan Metode IVA (Inspeksi Visual Dengan Asam Asetat). Jurnal Forum Ilmiah Volume 11 Nomor 2 Halaman 192-209 